\title{
Plant Metabolic Pathways in MetaCyc and SolCyc
}

Anuradha Pujar ${ }^{1}$, Ron Caspi ${ }^{2}$, Naama Menda ${ }^{1}$, Isaak Tecle ${ }^{1}$, Peter Karp² and Lukas Mueller ${ }^{1}$ Boyce Thompson Institute ${ }^{1}$, Cornell University, Ithaca, NY and Bioinformatics research Group, SRI International ${ }^{2}$, Menlo Park, CA

Introduction: MetaCyc is a metabolic encyclopedia of experimentally validated biochemical pathways, spanning all organisms, with an emphasis on microbes and plants.

\begin{tabular}{|ll|}
\hline $\begin{array}{l}\text { Current } \\
\text { Statistics }\end{array}$ & Feb 2009 \\
\hline Pathways & 1289 \\
\hline Organisms & 1683 \\
\hline Reactions & 7686 \\
\hline Enzymes & 5528 \\
\hline Genes & 5178 \\
\hline Compounds & 7722 \\
\hline
\end{tabular}

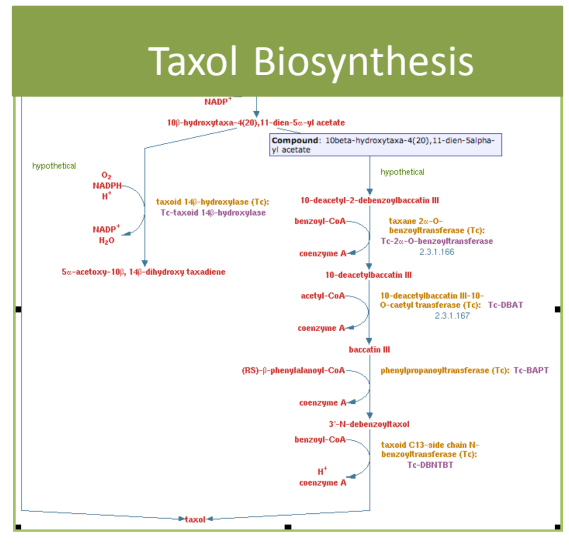

Pathway Tools Curation Software

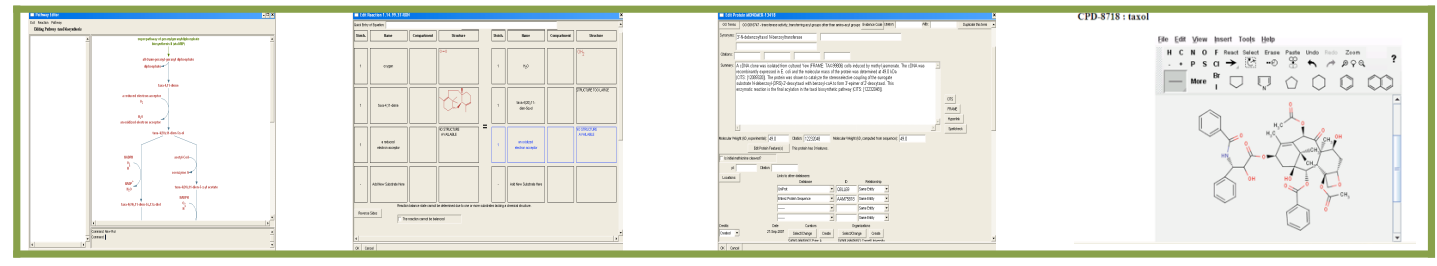

SolCyc - Pathway database in Solanceae Genomics Network (SGN), Genomic clade oriented database for Solanaceae
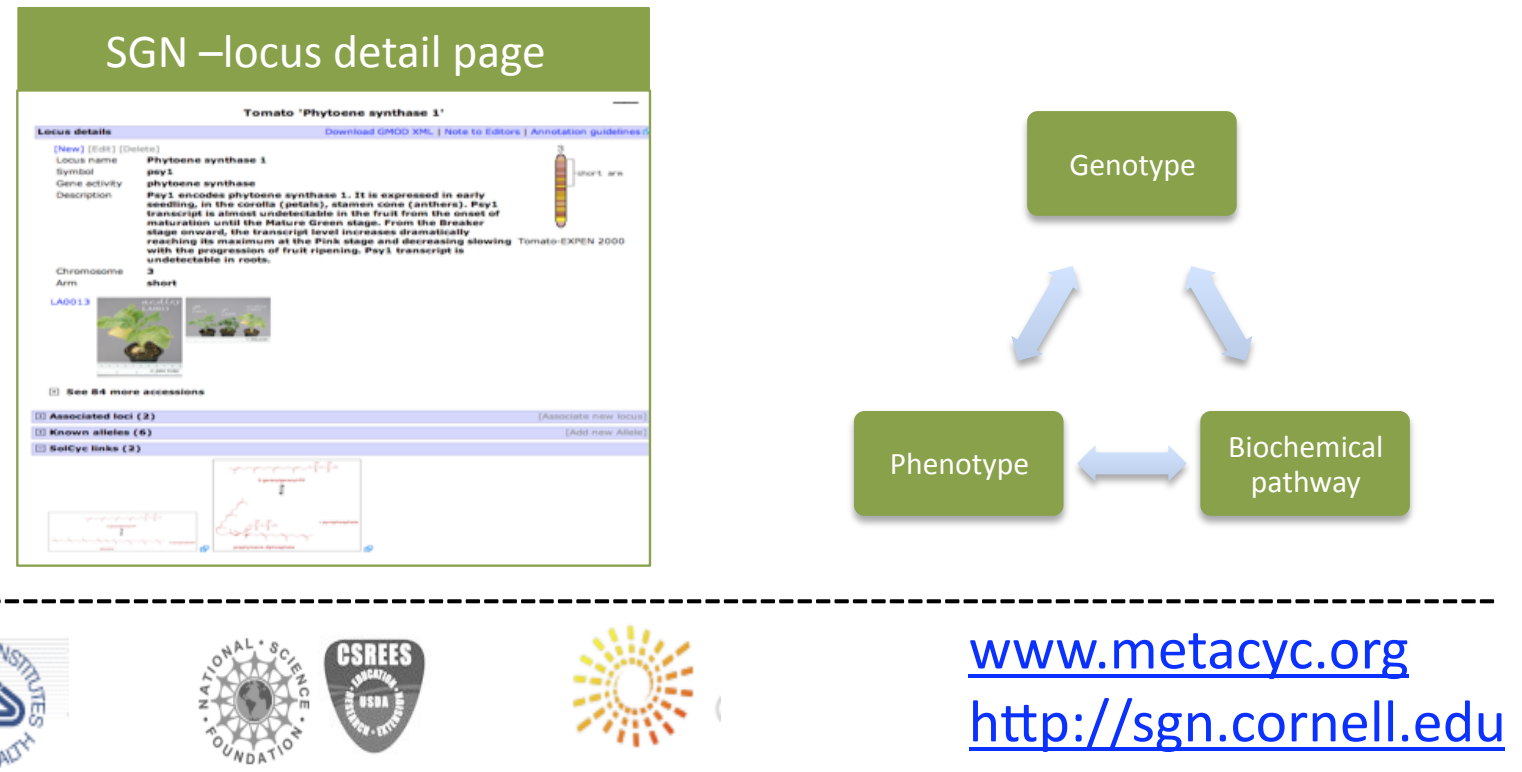